\title{
TAPHONOMY OF CAMBRIAN PHOSPHATIC SMALL SHELLY FOSSILS
}

\author{
JESSICA R. CREVELING,,$^{1,2}$ ANDREW H. KNOLL, ${ }^{1,3}$ AND DAVID T. JOHNSTON ${ }^{1}$ \\ ${ }^{1}$ Harvard University, Earth and Planetary Sciences, 20 Oxford Street, Cambridge, Massachusetts 02138, USA \\ ${ }^{2}$ California Institute of Technology, Geological and Planetary Sciences, MC 100-23, 1200 E. California Blvd., Pasadena, California 91125, USA \\ ${ }^{3}$ Harvard University, Organismic and Evolution Biology, 26 Oxford Street, Cambridge, Massachusetts 02138, USA \\ e-mail: jcrevel@gps.caltech.edu
}

\begin{abstract}
Small shelly fossils are preserved as apatite steinkerns in the Cambrian Series 2-3 Thorntonia Limestone, Australia. Petrological observations indicate that phosphorus delivered to Thorntonia sediment was remobilized before precipitating in microenvironments defined by the matrix-filled interiors of small, mostly conical skeletons. A previous geochemical study concluded that both organic matter and iron oxides sourced phosphorus to Thorntonia sediments, and that anoxia governed phosphorus remobilization within the sediment column. This contribution asks: What factors allowed for the selective preservation of skeleton interiors, and what biases result from this preservation? We find that small shells physically trapped phosphorus-laden pore waters, creating local conditions where kinetic barriers to apatite precipitation could be overcome. Only a subset of Thorntonia Limestone skeletons is preserved by apatite, showing evidence of selectivity with respect to shell size, shape, and orientation. Both the biological and physical factors that govern phosphorus remineralization and precipitation have changed through time, accounting for the opening and closing of the EdiacaranCambrian phosphatization taphonomic window. The opening of this window may have required a global increase in phosphate delivery to the oceans.
\end{abstract}

\section{INTRODUCTION}

Fossils record the history of life, but evolutionary and ecological interpretations based on this record depend, in part, on the nature of the taphonomic windows through which it is viewed. Both the benefits and limitations of differing preservational modes are apparent for the Ediacaran and Cambrian record of animal diversification (Butterfield 2003), raising the question: how do we weave a consistent paleobiological narrative through time-bounded Lagerstätten based successively on casts and molds in sandstone, phosphatic replication of skeletons in platform carbonates, and organic compressions in basinal black shales? To answer this question we must develop an understanding of the mechanisms and biases associated with each major taphonomic mode, addressing physical, chemical, and biological processes that governed fossilization in any particular assemblage and the global factors that opened and subsequently shuttered different preservational windows.

In this paper, we focus on small shelly fossils (SSFs), the distinctive skeletal assemblages (e.g., Bengston et al. 1990) that occur globally in Terrenuevian deposits and regionally in Cambrian Series 2-3 carbonates (Kouchinsky et al. 2012). SSFs can be preserved in a number of ways, but most stratigraphic and paleobiological interpretation is based on specimens preserved as phosphatic steinkerns, or internal molds. What mechanisms account for the preferential precipitation of penecontemporaneous apatite within shell interiors, and how well does this process capture skeletal diversity? Why do phosphatic steinkerns fade from paleontological view after the midCambrian (Porter 2004a)?

To address these questions, we present a case study of SSF preservation from the Cambrian Series 2-3 Thorntonia Limestone, southern Georgina Basin, Australia. We chose this location because a preexisting sequence stratigraphic framework (Southgate 1988) places phosphatized fossils in physical environmental context, and detailed geochemical analyses (Creveling et al. 2014) constrain both redox environment and the sources of phosphorus (P) for apatite precipitation. In concert with these stratigraphic and geochemical data, petrographic observations presented here allow us to develop a mechanistic hypothesis for calcium phosphate steinkern precipitation in Thorntonia sediment. This, in turn, prompts us to ask which of the environmental circumstances and (bio)geochemical processes necessary for phosphate replication varied through time in a pattern consistent with the temporal and spatial dimensions of the observed taphonomic window.

Detailing the Ediacaran-Cambrian phosphate window will contribute to our knowledge of both biological and environmental history. Moreover, insofar as phosphate minerals constitute a fundamental and diminishing resource for fertilizers applied globally in agriculture, as well as a principal source of the rare earth elements critical to 21 st century technologies, there is practical benefit to understanding the circumstances under which phosphate deposition waxed and waned during the Ediacaran and Cambrian periods.

\section{DIMENSIONS OF THE EDIACARAN-CAMBRIAN PHOSPHATIZATION WINDOW}

Phosphatized microfossils occur sporadically in both marine (Knoll and Vidal 1980; Bengtson et al. 2009; Edwards et al. 2012) and purportedly lacustrine (Battison and Brasier 2012) rocks of pre-Ediacaran age. The phosphatization taphonomic window, however, opened widely only during the middle of the Ediacaran Period, preserving a range of small, soft-bodied remains that includes multicellular algae (Xiao et al. 2004) and animal embryos (Xiao and Knoll 1999; Hagadorn et al. 2006) or basal holozoans (Huldtgren et al. 2011). Undisputed embryos occur 
relatively widely in lower Cambrian (Stage 2) deposits, but only sporadically in younger rocks up to the lower Ordovician (Donoghue et al. 2006). Curiously, fossil embryos younger than Stage 2 (Tommotian) are limited to Markuelia, whose formation of cuticle at an early stage of development evidently predisposed it to phosphatic replication (Briggs 2003; Butterfield 2003; Donoghue et al. 2006). Cuticle also appears to have played a critical role in so-called Örsten-style preservation, which provides a high-fidelity window into small arthropods and other invertebrates throughout the Cambrian Period (Maas and Waloszek 2001; Waloszek 2003; Maas et al. 2006; Shen et al. 2013).

Phosphatic preservation of skeletal organisms began with the first appearance of macroscopic skeletons in the late Ediacaran Period (Bengtson and Zhao 1992) and expanded with the earliest Cambrian (Terreneuvian) radiation of skeleton-forming animals (e.g., Bengtson et al. 1990; Maloof et al. 2010). This window largely closed, however, by the end of Cambrian Series 2-3 (Porter 2004a). SSFs can be preserved as original shell material, silica replacements of skeletons, or internal molds of either pyrite or iron oxides (Porter 2004a), but most reports focus on phosphatized remains, which are overwhelmingly steinkerns (e.g., Bengtson et al. 1990; Gubanov and Peel 2003; Skovsted 2004; Kouchinksy et al. 2009; Parkhaev and Karlova 2011). Porter (2004a) quantified the distribution of Cambrian phosphatic lithologies, evaluating the possibility that taphonomic bias contributed to the observed decline in SSF diversity through Cambrian time. Her data indicate that phosphatized assemblages declined significantly through the period, from $75 \%$ of total SSF-bearing occurrences in the earliest Cambrian to $40 \%$ in Cambrian Series 2-3. In Furongian successions, phosphorites and phosphatic carbonates are even less common (Cook and Shergold 1984).

With regard to the spatial dimensions of the phosphatization taphonomic window, Brasier and Callow (2007) reported a secular change in environments of phosphatization, shifting from shallow marine, photic zone phosphatization in Ediacaran deposits toward outer shelf/slope environments by the later Cambrian. These authors underscored the concomitant change through time in both the quality of preservation and the taxonomy of phosphatized remains.

This synopsis makes clear what needs to be explained. At the local level, what processes (1) introduced phosphate into sediments, (2) remobilized phosphate within the sediment column, and (3) governed apatite precipitation in specific, localized microenvironments defined by SSFs? More broadly, what features of biology, environment, or both define the three global dimensions of the phosphatization taphonomic window for skeletal fossils: temporal duration, facies distribution, and fidelity of preservation? We begin by enumerating preservation mechanisms responsible for SSF preservation in the Thorntonia Limestone and then reflect on how these mechanisms may relate to the global closure of the Ediacaran-Cambrian phosphatization taphonomic window.

\section{THORNTONIA LIMESTONE: STRATIGRAPHY AND SEDIMENTOLOGY}

The Georgina Basin, located within the present-day Northern Territories and Queensland, Australia, is one of several interconnected basins, collectively termed the Centralian Superbasin, which formed in response to rifting of the supercontinent Rodinia during the Neoproterozoic Era (Fig. 1A; Walter et al. 1995; Lindsay 2002). Dunster et al. (2007) provided a comprehensive synopsis of tectonostratigraphy within the southern Georgina Basin, summarized only briefly here. A carbonate platform developed across the southern Georgina Basin during the early Cambrian, represented by the Shadow Group. After a brief regional erosive event, platformal carbonate deposition resumed, depositing the overlying Cambrian Series 2-3 Thorntonia Limestone and Arthur Creek Formation. The Thorntonia Limestone hosts phosphorite and phosphatized skeletal fossils (Dunster et al., 2007) and strata correlative to the overlying Arthur Creek Formation yield both phosphatized skeletal
(Porter, 2004b) and soft-bodied (Waloszek et al. 1993) fossils. Broadly, Southgate $(1986,1988)$ described the Thorntonia Limestone as stacked shallowing-upward parasequences, with phosphorite accumulating in wave-influenced shallow marine facies and phosphocrete developing in the emergent, or near-emergent intertidal portion of shallowing-upward cycles.

Creveling et al. (2014) examined the Thorntonia Limestone within drillcore NTGS 99/1 from the depocenter of the southern Georgina Basin. Within NTGS 99/1, the Thorntonia Limestone comprises three distinct carbonate lithologic units (consistent with brief descriptions by Dunster et al. 2007). The lower unit (Fig. 1B; 598.4-580.1 meters core depth (mcd)) consists of dolomudstone and dolowackestone with pervasive structural dissolution textures. The middle Thorntonia Limestone contains four interbedded lithofacies that occur within generally coarsening-upward meter- to submeter-scale packages (Fig. 1B; 580.1$558.7 \mathrm{mcd}$ ). These lithofacies include black to medium-gray carbonate mudstone and wackestone, bioclastic packstone, and minor bioclastic grainstone. Bioclasts within the middle Thorntonia Limestone include phosphatized fossils, described in detail below. The upper Thorntonia Limestone encompasses a four-meter thick, vuggy, bioclastic dolopackstone (Fig. 1B; 558.7-554.7 mcd); lingulid brachiopods are the predominant bioclasts in this unit.

\section{PETROGRAPHY OF PHOSPHATIC SKELETAL FOSSIL PRESERVATION}

Apatite occurs in four modes within the Thorntonia Limestone. As noted in the previous section, lingulid brachiopod bioclasts of primary calcium phosphate minerals are locally abundant in upper Thorntonia dolopackstone and occur sporadically in other facies. As these bioclasts do not result from secondary replacement and do not constitute a quantitatively important source of phosphate to SSF steinkerns (see below), they shed little light on phosphatization taphonomy. Within bioclastic wackestone and packstone of the middle Thorntonia Limestone, however, apatite forms the internal molds of ovoid, conical, and, rarely, campanulate and pentate SSFs (Figs. 2 and 3AI). Apatite can also occlude the small volume bound by nested shells (lower left of Fig. 2A; Fig. 3J). Elemental analysis by scanning electron microscope energy-dispersive X-ray spectroscopy (SEM-EDX) supports the petrographic observation that apatite precipitation occurred only in specific microenvironments in the interiors of SSFs (Figs. 4AB). In bioclastic packstone and wackestone, apatite did not precipitate as a matrix phase or as cement surrounding grains (Figs. 4A, C). Petrography also reveals that many skeletal elements were at least partially filled with micrite and fine-grained calcitic bioclasts prior to phosphatization (e.g., Figs. 3A, D, H); apatite nucleation and growth within shell interiors must have dissolved matrix carbonate in a way that preserved original sediment textures at a fine scale. When present, bounding carbonate skeletons are preserved as neomorphosed, drusy calcite microspar (Figs. 3A-I).

The petrographic observation that steinkerns replaced carbonate matrix within shell interiors and entombed calcitic shell fragments indicates that the skeletons were transported to their depositional site as bioclasts; soft tissue decay predated deposition and so cannot have provided a significant local source of phosphate (discussed further in a later section). From skeletons displaying incomplete molding by apatite, we infer that phosphatization proceeded from the vertex toward the aperture of skeletons with conical morphologies, and from the exterior to the interior of spherical/oblate morphologies (Figs. 3B-C, F). The internal molding of skeletons occurred prior to complete dissolution of the bounding skeleton, as evidenced by the sharp margins of steinkerns (Figs. 3A-F).

The third type of apatite occurrence is local cryptocrystalline cement within bioclastic grainstone (Fig. 2B). Steinkerns of conical, ovate, and 


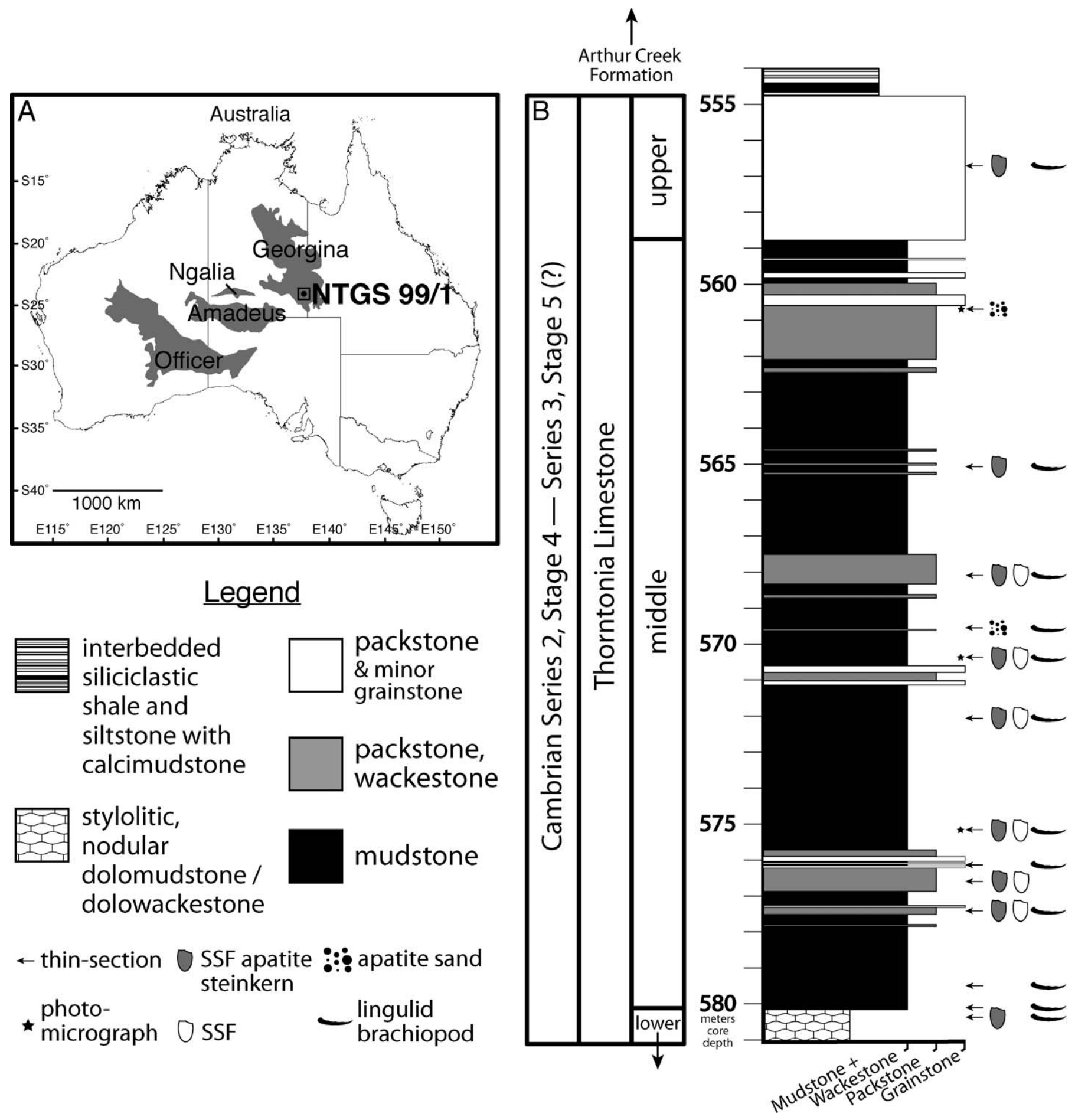

FIG. 1.-Location map and generalized stratigraphic column of the middle and upper units of the Thorntonia Limestone from drill core Northern Territory Geological Survey (NTGS) 99/1. A) Map of Australia with insert box of the drill site of core NTGS 99/1 within the southern Georgina Basin, Australia (adopted from Creveling et al. 2014). B) Stratigraphic column highlighting the lithology and paleontology of the middle Thorntonia Limestone in drill core NTGS 99/1. See legend for explanation of the symbols on the right side of the stratigraphic column.

campanulate small shelly fossils appear more frequently in this lithology than in packstone without apatite matrix or grainstone without apatite cement (Figs. 2B and 5A-B). Within these lithologies, echinoderm ossicles appear with greater abundance and, generally, with higher fidelity preservation (Fig. 5C); nevertheless, ossicles often display neomorphic microspar interiors with patches of phosphatization (Fig. 5D). Cementation of bioclasts by apatite (Fig. 2B) suggests that phosphate occurred as a mobile phase that encased bioclasts, occluding primary porosity.

Finally, carbonate wackestone of the Thorntonia Limestone hosts subangular to subrounded and tabular to undulose silt to medium-sandsized apatite grains within well-sorted laminae (Fig. 6A). Tabular and undulose grains largely comprise lingulid brachiopod shell fragments, but 




FIG. 2.-Photomicrographs of apatite distribution within lithologies of the middle Thorntonia Limestone (modified from Creveling et al. 2014). Scale bar in each frame is $3 \mathrm{~mm}$. A) Sample NTGS 570.35 meters core depth (mcd), a wackestone with apatite steinkerns of small shelly fossils (SSFs). Small inset box outlines the SEMEDX map area shown in Figure 4A. B) Sample NTGS 575.17 mcd, grainstone with apatite cement and packstone with apatite steinkerns of SSFs.

other grains appear to represent eroded and redeposited authigenic apatite, including both steinkerns (Figs. 6B-C) and intraclasts of cement or hardgrounds. (See Creveling et al. (2014) for more detailed discussion of petrographic and geochemical data indicating that this is not igneous/ metamorphic apatite associated with a detrital siliciclastic influx.) For carbonate mud-supported lithologies, SEM-EDX elemental analysis confirms that phosphorus is a rare component of the matrix, and is (mostly) confined to these allochthonous, authigenic grains (Fig. 7).

\section{LOCAL CONTROLS ON MIDDLE THORNTONIA LIMESTONE PHOSPHATIZATION TAPHONOMY}

Apatite precipitation requires both pore water saturation with respect to this mineral and favorable kinetics for nucleation. Thus, a complete understanding of apatite precipitation in marine sediment would require that we fully constrain the relative budgets of calcium; phosphorus; anions, such as $\mathrm{CO}_{3}{ }^{2-}, \mathrm{F}^{-}$and $\mathrm{OH}^{-}$; and the $\mathrm{pH}$ of pore water environments (Jahnke et al. 1983; Froelich et al. 1988). These factors can be difficult to quantify even in modern environments where geochemical, biological, and hydraulic processes can be observed (e.g., Jahnke et al. 1983; Froelich et al. 1988). With this in mind, we employed a combination of petrographic observations and geochemical data to infer pore water processes that induced steinkern precipitation in the Thorntonia Limestone.

\section{Sources of Phosphorus to the Middle Thorntonia Limestone}

At the most fundamental level, phosphatization taphonomy requires that sufficient quantities of phosphorus be delivered to the sediment 

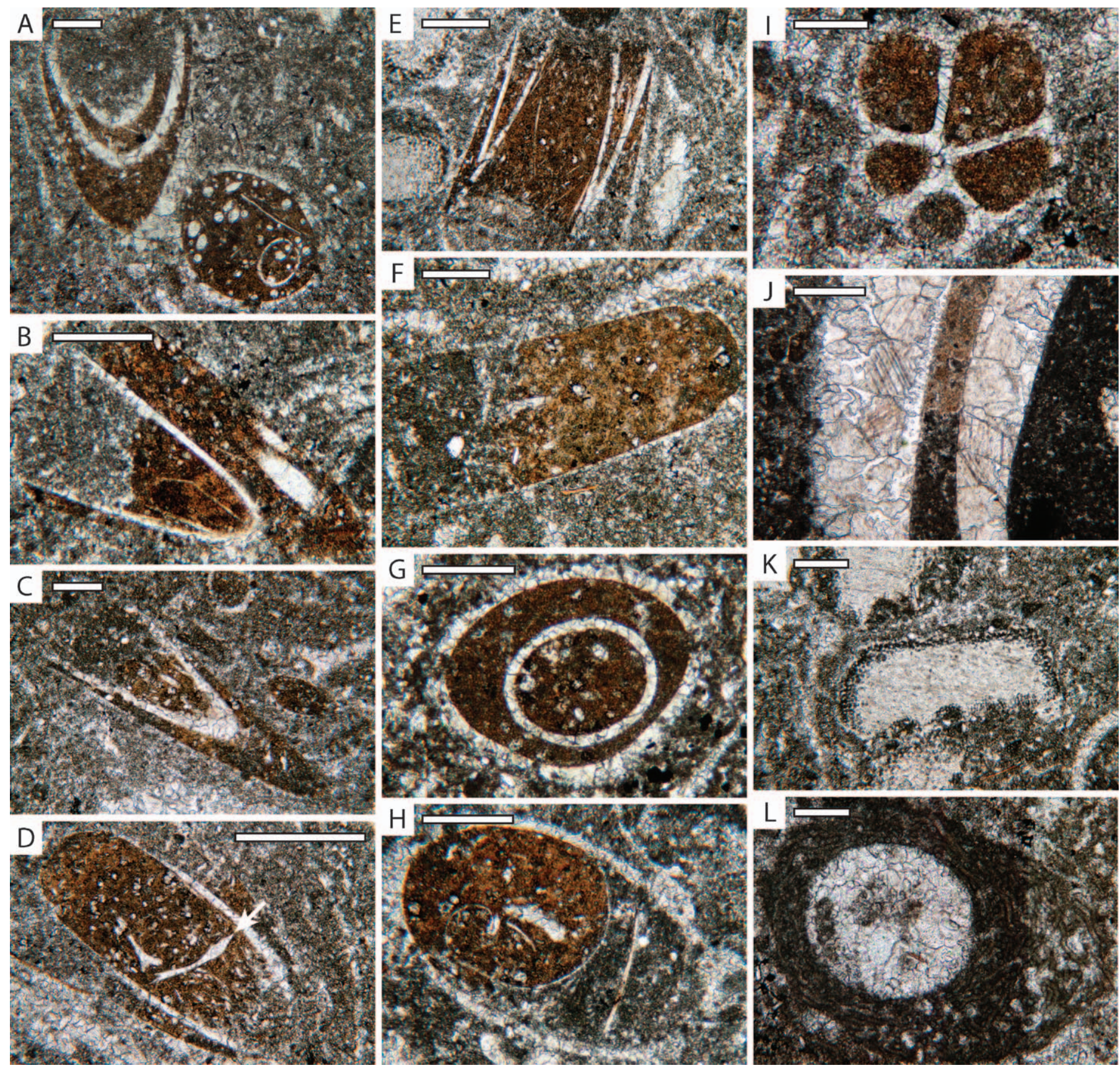

FIG. 3.-Photomicrographs of apatite steinkerns of small shelly fossils and other fossil preservational modes from sample NTGS 99/1 570.35 mcd. Scale bar in each frame is $400 \mu \mathrm{m}$. A-I) Apatite steinkerns of small shelly fossils. The white arrow in frame D points to a carbonate bioclast preserved within an apatite steinkern. J) Apatite replacing the small volume between two concentric hyolith shells. K) A neomorphosed echinoderm ossicle. L) A Girvanella oncolitic halo surrounding a neomorphosed calcite steinkern. The distinctive shapes of individual steinkerns and fossils can be seen within their petrologic context in the upper left $(\mathrm{K})$, upper center $(\mathrm{C})$, upper right $(\mathrm{F})$, middle left $(\mathrm{H}-\mathrm{I})$, middle center $(\mathrm{D})$, middle right $(\mathrm{E})$, lower left $(\mathrm{G}, \mathrm{J}, \mathrm{L})$, lower center $(\mathrm{A})$ and lower right (B) of Figure 2A

column under circumstances that prevented subsequent $\mathrm{P}$ loss to the overlying water column. Some authors propose that animals themselves supplied the phosphate for phosphatic preservation. This may be the case for patchy phosphatization of muscle and other soft tissues (e.g., Briggs and Kear 1993), but in general, phosphate is thought to be sourced externally (Wilby and Briggs 1997). Two considerations make it clear that phosphorus in the soft tissues of invertebrates could not account for Thorntonia steinkerns. First, the presence of carbonate bioclasts within apatite steinkerns (Figs. 3A, D, H) shows that the soft tissues of
Thorntonia SSFs decayed prior to phosphatization and the hollow shell was subsequently filled with carbonate sediment. This observation suggests that much, if not all, of the phosphate released during organic decay of the invertebrate organism would have advected/diffused away from the shell interior before it was filled with bioclastic carbonate sediment. Secondly, for apatite to replace a volume previously occupied by organic matter, the amount of phosphorus within both phases must be similar. However, both the mass fraction of phosphorus $\left(f_{P}\right)$ within apatite $\left(\mathrm{Ca}_{10}\left(\mathrm{PO}_{4}\right)_{5}\left(\mathrm{CO}_{3}\right) \mathrm{F}\right)$ and the density $(\rho)$ of apatite 

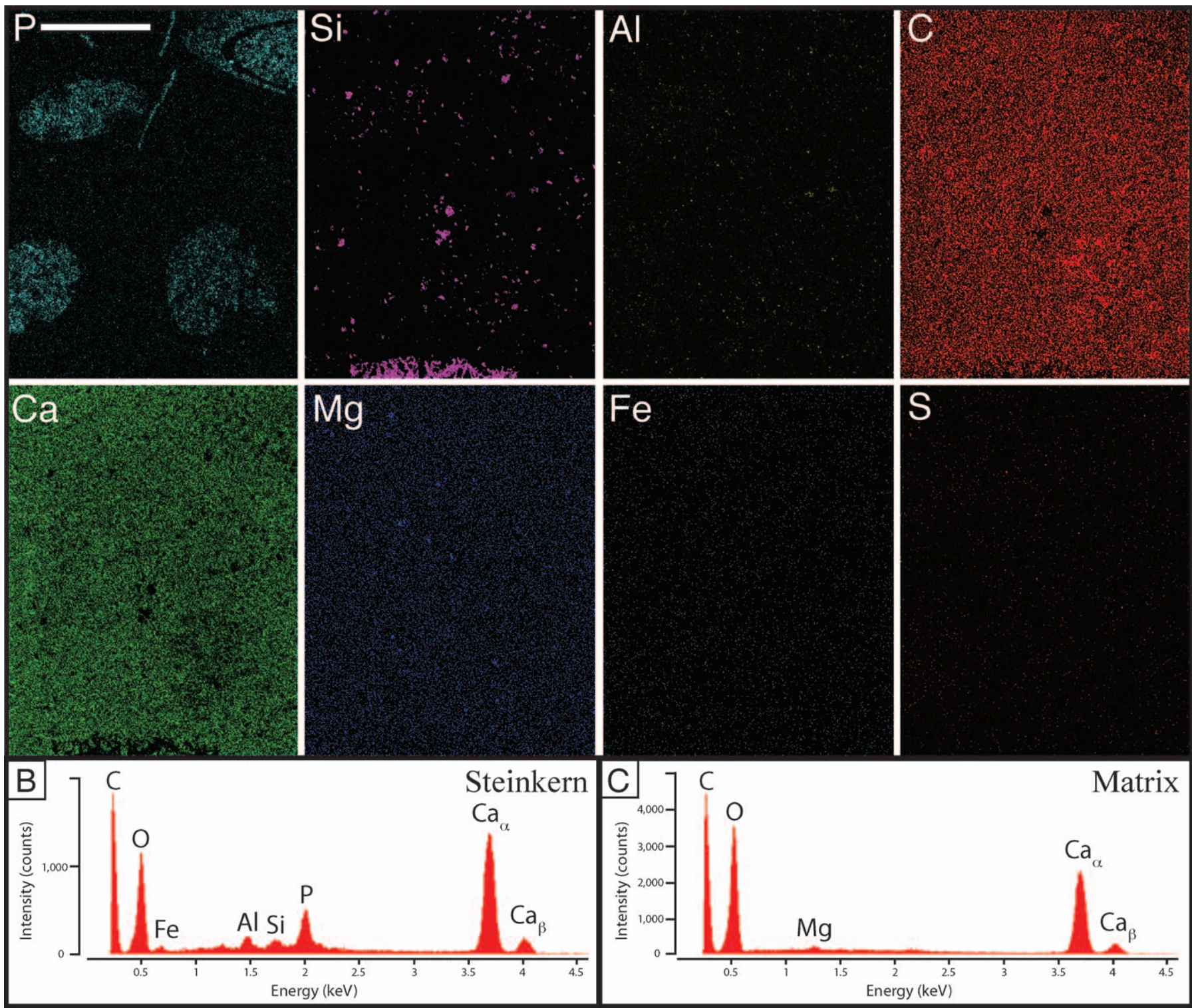

FIG. 4.-Scanning electron microscope energy-dispersive X-ray spectroscopy (SEM-EDX) major element maps and spectra of steinkerns within a packstone of the middle Thorntonia Limestone (sample NTGS 99/1 $570.35 \mathrm{mcd}$; see inset box in Fig. 2A for petrographic character). A) SEM-EDX elemental maps of phosphorus (=P), silicon $(=\mathrm{Si})$, aluminum $(=\mathrm{Al})$, carbon $(=\mathrm{C})$, calcium $(=\mathrm{Ca})$, magnesium $(=\mathrm{Mg})$, iron $(=\mathrm{Fe})$ and sulfur $(=\mathrm{S})$. Scale bar is $0.5 \mathrm{~mm}$. Views B and C show SEM-EDX spot analysis spectra of the number of X-rays detected in a single spot analysis (intensity (counts)) versus the energy (keV) of the X-ray; X-ray energies are characteristic of specific elements, which are labeled above the intensity peaks. B) A spot analysis of a steinkern reveals calcium and phosphorus peaks indicative of apatite. C) Consistent with elemental maps, a spot analysis spectrum reveals a carbonate matrix without dispersed apatite (note the absence of a P peak on this spectrum).

exceed those of organic matter with a Redfield stoichiometry $\left(\mathrm{C}_{106} \mathrm{H}_{212} \mathrm{O}_{106} \mathrm{~N}_{16} \mathrm{P}\right)$ :

$$
f_{P, \text { apatite }}\left(\rho_{\text {apatite }} \times v\right) \gg f_{P, \text { org } C}\left(\rho_{\text {org } C} \times v\right) \text {. }
$$

where $v$ represents the internal volume of a skeleton. Imperfections in the apatite lattice and/or microscale secondary mineral phases (such as a carbonate) would decrease the amount of phosphorus necessary for apatite steinkern development, but the large difference between the mass fractions of phosphorus in apatite and organic matter $(\sim 16 \%$ versus $\sim 0.9 \%$, respectively) suggests that any such secondary mineral phases would have to be a dominant component of the steinkern mineralogy, and they are not. Thus, to precipitate an apatite steinkern, an additional source of phosphorus must augment that derived from any in situ remineralization of the organism's own tissues.

One might also reason that phosphatic skeletons could provide a source of phosphorus for phosphatic steinkerns; however, two simple observations militate against this hypothesis for the Thorntonia Limestone. Where the shells of lingulid brachiopods are common, phosphatized SSFs are not, and where phosphatized internal molds of SSFs are common, lingulid debris is only a minor component of bioclasts. Moreover, in thin section, lingulid bioclasts show little evidence of dissolution during diagenesis. For these reasons, lingulid shells do not appear to have contributed significantly to the phosphorus in Thorntonia steinkerns (Creveling et al. 2014). What, then, were the sources of phosphorus to the middle Thorntonia Limestone? 

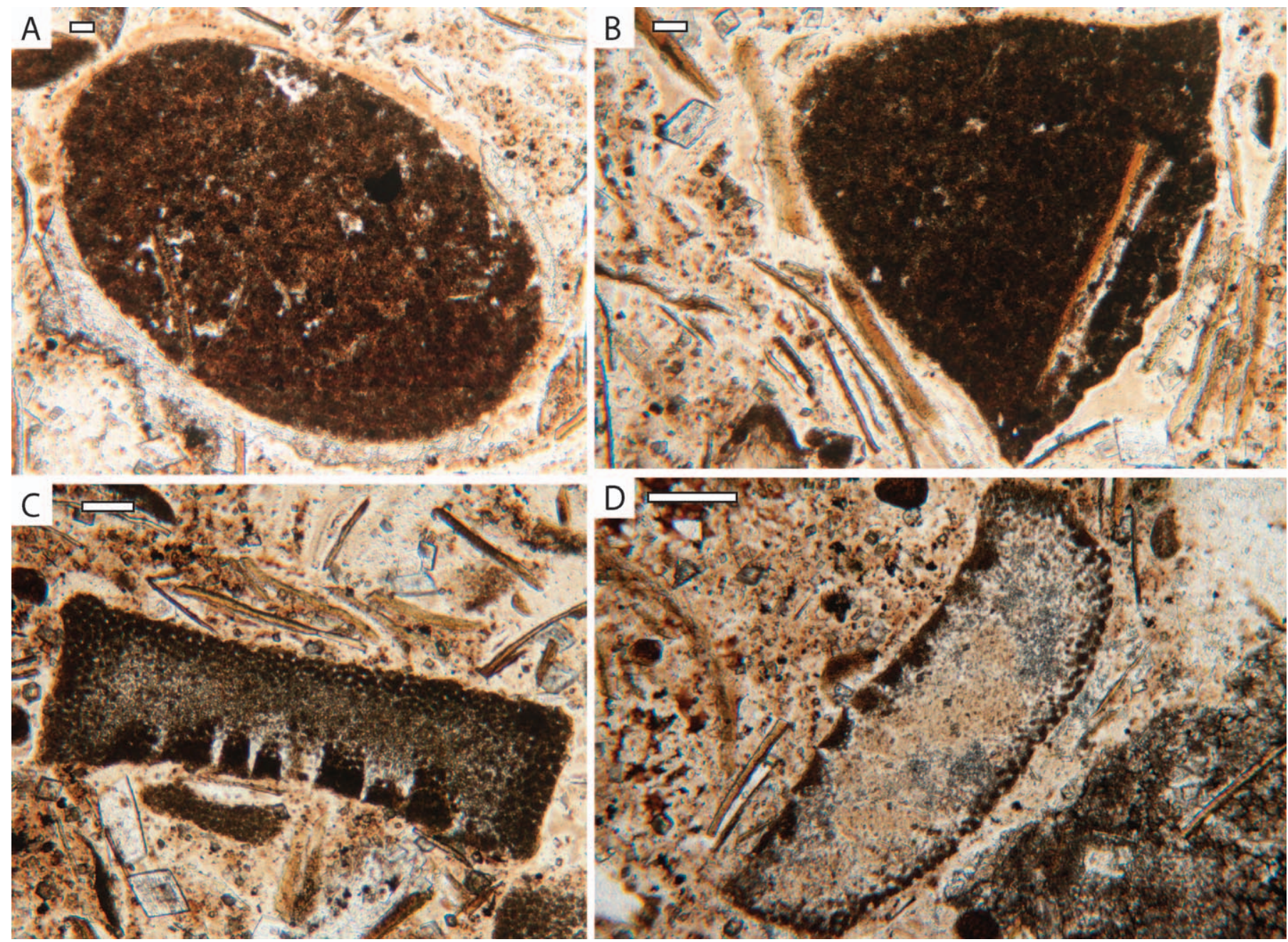

FIG. 5.-Photomicrographs of fossil preservation within apatite cement, sample NTGS 99/1 575.17 mcd. (See thin-section photomicrograph in Fig. 2B.) Scale bar in each frame is $100 \mu \mathrm{m}$. A) Apatite steinkern of an ovate small shelly fossil. See center left of Figure 2B. B) Apatite steinkern of a campanulate small shelly fossil. See center left of Figure 2B. C) Echinoid ossicle replaced by apatite. See center right of Figure 2B. D) Echinoid ossicle with neomorphosed carbonate spar subsequently replaced by apatite cement. See lower right of Figure 2B.

In modern environments, phosphorus bound to particulate organic matter and adsorbed to iron $(\mathrm{Fe})$ minerals constitute the two most significant reactive phosphorus fluxes to the sediment column (Delaney 1998), and this appears to be the case for ancient phosphatic lithologies as well (e.g., Föllmi et al. 2005; Dornbos et al. 2006; März et al. 2008). Creveling et al. (2014) used geochemical analyses of total organic carbon, iron speciation, and phosphorus speciation to assess the relative importance of organic- and iron-bound phosphorus delivery to the seafloor during Thorntonia deposition, comparing the preserved organic carbon content within Thorntonia core samples to the quantity of organic matter predicted to source the observed phosphorus content if organic matter were delivered with a Redfield stoichiometry. From these calculations, they concluded that, by itself, phosphorus released from organic matter remineralization could not have sourced the observed apatite enrichment; moreover, these authors argued that if organic matter had been delivered to the Thorntonia Limestone with a C:P ratio greater than the canonical Redfield ratio, as is common in modern sediment (Clark et al. 1998; Algeo and Ingall 2007), the deficiency of the organic-bound P shuttle would be even greater.

Based on iron geochemical data, Creveling et al. (2014) further concluded that Thorntonia phosphorus deposition occurred under an anoxic, ferruginous subsurface water mass, suggesting that phosphorus could also have been delivered to Thorntonia sediments bound to iron minerals that precipitated from the water column. However, these authors noted that under reasonable constraints on advective/diffusive loss of iron from the Thorntonia sediment column, Fe-bound P could not account for all of the phosphorus necessary for Thorntonia apatite authigenesis. Therefore, they concluded that both organic matter and iron oxides contributed phosphorus to Thorntonia sediments.

Regardless of the depositional mechanism, petrological observation shows that phosphorus within the Thorntonia Limestone is no longer associated with these two delivery phases, but rather occurs predominantly, and in many samples exclusively, as apatite steinkerns. Thus, understanding phosphatization taphonomy requires that we not simply account for phosphorus delivery, but also identify the mechanism(s) that decoupled phosphorus from delivery shuttles and transformed it to a soluble (mobile) ion that contributed to authigenic apatite precipitation.

\section{Mechanism for Phosphorus Redistribution in the Middle Thorntonia Limestone}

Aerobic and anaerobic respiration release organic-bound $\mathrm{P}$, and in particular, microbial iron reduction simultaneously releases phosphorus 

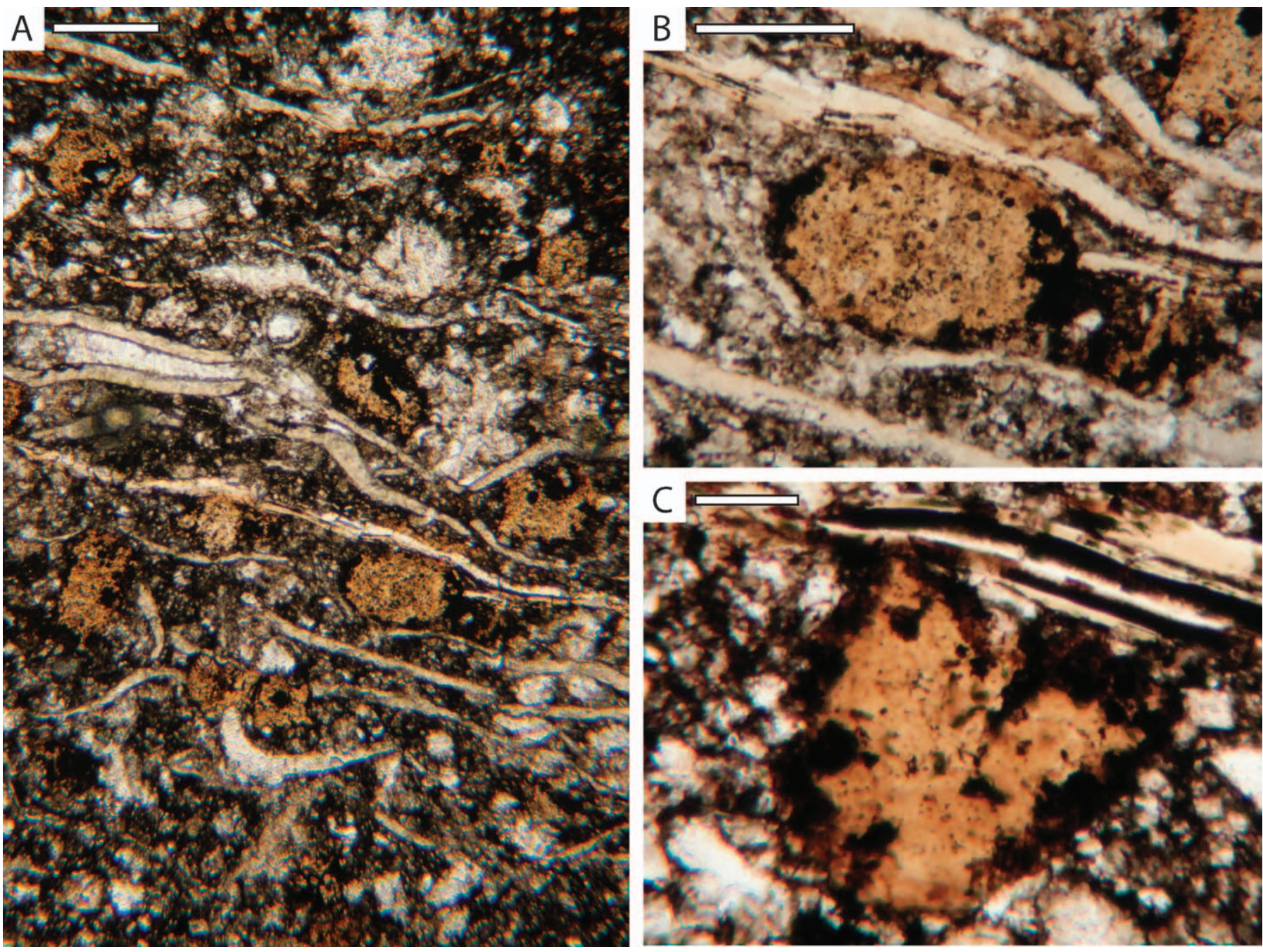

FIG. 6.-Photomicrographs of apatite distribution within wackestone of the middle Thorntonia Limestone sample NTGS 99/1 560.69 mcd. A) Lingulid-brachiopodand apatite-sand-bearing wackestone. Scale bar is $250 \mu \mathrm{m}$. B) An apatite sand grain (from the center of view A inferred to represent a transported ovate steinkern (see text for discussion). Scale bar is $125 \mu \mathrm{m}$. C) A transported conical apatitie steinkern with opaque (pyrite) mineral inclusions. Scale bar is $125 \mu \mathrm{m}$.

bound to iron minerals (e.g., Krom and Berner 1981). We thus suggest that microbial respiration was the principal process that released phosphate to Thorntonia pore waters. Once released from a delivery source, regenerated $\mathrm{PO}_{4}{ }^{3-}$ would have incurred one of three fates (Froelich et al. 1982): (1) it could advect or diffuse into the overlying water column, (2) as a bioessential element, it could cycle between organic matter production and remineralization within the sediment column - a so-called regeneration loop-before being buried as organic-bound phosphorus, or (3) it could precipitate from pore waters as an authigenic phase.

In the classical view, sedimentary retention of phosphate ions is largely controlled by the redox-dependent speciation of iron: ferric iron minerals adsorb phosphate, but the reductive dissolution of these minerals releases adsorbed phosphate back to solution (Berner 1973; Van Cappellen and Ingall 1996; Algeo and Ingall 2007). In sediment overlain by an anoxic water mass, remobilized phosphorus might well be lost to the water column through advection/diffusion (e.g., Ingall et al. 1993; Van Cappellen and Ingall 1994) unless some additional mechanism keeps it from leaving; in contrast, when the anoxic-oxic chemocline remains within the sediment column, released phosphorus can be trapped within the sediment column through biological sequestration and adsorption/coprecipitation onto (iron) oxide minerals along this interface (e.g., Algeo and Ingall 2007). Phosphorus trapping within the sediment column, however, appears to be necessary but not sufficient for apatite authigenesis because $\mathrm{PO}_{4}{ }^{3-}$ that remains (or becomes) bound to iron oxides may be buried as Fe-P minerals, preventing it from contributing to authigenic apatite precipitation. Thus, the iron-based model for sedimentary apatite authigenesis necessitates a dynamic redox cycle that traps and concentrates $\mathrm{PO}_{4}{ }^{3-}$ ions within $\mathrm{Fe}-\mathrm{P}$ minerals at an oxic interface and then reductively dissolves them, allowing $\mathrm{PO}_{4}{ }^{3-}$ ions to saturate sediment pore waters and facilitate apatite precipitation (see Algeo and Ingall 2007, and references therein). Within this paradigm, oxygen-replete conditions do not seem to favor widespread apatite formation, but fluctuating oxic and anoxic ferruginous conditions may.

Nevertheless, redox-dependent coupling of the sedimentary iron and phosphorus cycles cannot satisfactorily explain the limited temporal and changing stratigraphic distribution of phosphorite through the geologic record reported by Brasier and Callow (2007). The oxic-anoxic interface was probably located within nearshore sediment for much of the Proterozoic Eon, given geochemical data indicating that deeper waters were anoxic (Canfield et al. 2008; Lyons et al. 2014), yet few phosphorites developed during this interval (Cook and Shergold 1984). 

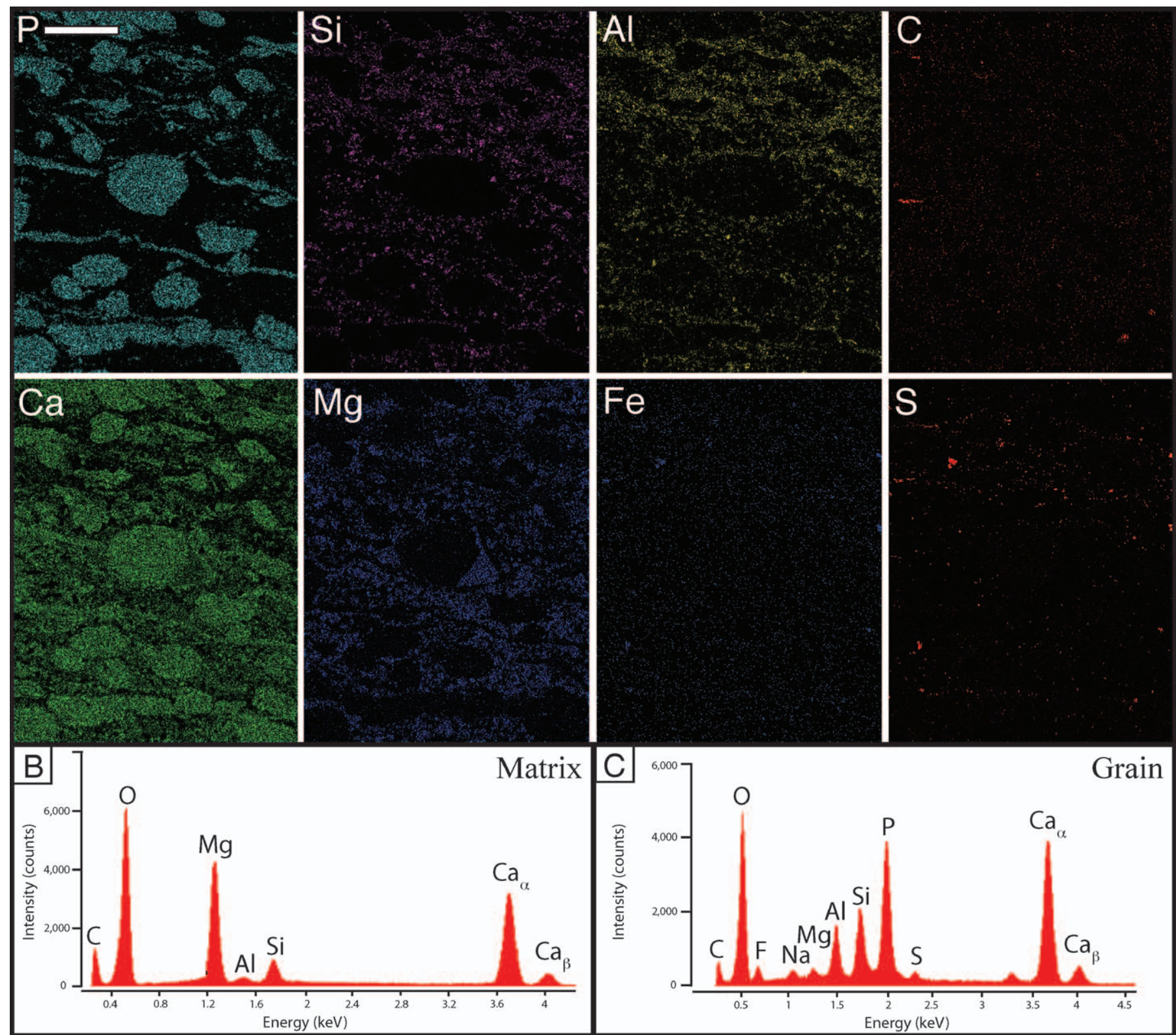

FIG. 7.-Scanning electron microscope energy-dispersive X-ray spectroscopy (SEM-EDX) maps and spectra of authigenic, allocthonous phosphatic grains within a wackestone of the middle Thorntonia Limestone (sample NTGS $560.69 \mathrm{mcd}$ ). A) The elemental distribution (see Fig. 4 caption for element symbols) of this sample reveals a dolomitic $(\mathrm{Ca}, \mathrm{Mg})$ and siliciclastic $(\mathrm{Si}, \mathrm{Al})$ matrix with grains of apatite $(\mathrm{P}, \mathrm{Ca})$ and minor pyrite $(\mathrm{Fe}, \mathrm{S})$. Scale bar is $250 \mu \mathrm{m}$. B) A spot analysis spectrum (see explanation in the caption to Fig. 4) of the matrix confirms this distribution, and emphasizes the absence of phosphorus. C) A spot analysis spectrum of a constituent grain reveals large $\mathrm{Ca}$ and $\mathrm{P}$ peaks, consistent with apatite mineralogy, as well as an apparent close association between siliciclastic ( $\mathrm{Al}, \mathrm{Si})$ and pyrite (Fe, $\mathrm{S})$ minerals.

In recent years, limnologists have refined their thinking about phosphorus retention in sediments, recognizing additional factors of potential importance, including pore water sulfate concentration ( $\left[\mathrm{SO}_{4}{ }^{2-}\right]$; Caraco et al. 1989; Hupfer and Lewandowski 2008). Experiments by Caraco et al. (1989) showed that at the high sulfate levels characteristic of modern seawater, phosphorus retention tended to be low whether sediments were oxic or anoxic. When $\left[\mathrm{SO}_{4}{ }^{2-}\right]$ was low $(100$ $300 \mu \mathrm{M}$ ), retention was enhanced, again regardless of redox state. Only at intermediate sulfate concentrations did redox state govern phosphorus retention in the classically expected manner discussed above (Caraco et al. 1989). Why would this be the case? Sulfate availability allows for dissimilatory sulfate reduction, which generates sulfide $\left(\mathrm{H}_{2} \mathrm{~S}\right)$ that removes iron from pore waters through pyrite (or other iron-sulfide) precipitation; when iron is titrated into iron sulfide minerals, $\mathrm{PO}_{4}{ }^{3-}$ cannot adsorb to iron-oxide surfaces and instead remains as a dissolved ion in pore waters (Caraco et al. 1989). We note that phosphate competes with additional anions for reactive $\mathrm{Fe}$ surfaces, including silica (Konhauser et al. 2007) and trace elements (Feely et al. 1991, 1998); these important relationships are difficult to track through Earth history, although the Cambrian radiations of siliceous sponges and radiolarians should have acted to decrease seawater silica concentrations (Maliva et al. 1989). Correlating sedimentary phosphorus retention to sulfate availability still ties phosphogenesis to pore water oxidation state, but through the oxidative sulfur cycle rather than the redox state and speciation of iron minerals. In turn, the sulfur cycle is coupled to the iron cycle through sulfide scavenging of sedimentary iron (e.g., Berner 1984). 
Sulfate reduction lowers pore water $\mathrm{pH}$ in the absence of iron to scavenge hydrogen sulfide (Ben-Yaakov 1973; Soetaert et al. 2007; Bergmann et al. 2013). Some disagreement exists in the literature over the role of pore water $\mathrm{pH}$ in mediating apatite nucleation. Moore and Reddy (1994) reported that processes that acidify pore water act to increase apatite solubility, leading to the dissolution of apatite minerals. In contrast, theoretical calculations suggest that lower $\mathrm{pH}$ increases apatite stability while simultaneously decreasing carbonate stability (Nathan and Sass 1981). Experiments on soft-tissue phosphatization preservation of shrimp (Briggs and Kear 1993, 1994; Sagemann et al. 1999) similarly indicate that lower $\mathrm{pH}$ favors the precipitation of apatite on muscle tissue; soft tissue was rarely preserved (or preserved through carbonate bundles) when pH remained around 8. Likewise, Glenn and Arthur (1988) and Arning et al. (2009) reported petrographic observations of carbonate fluorapatite nodule and laminite formation coeval with pyrite precipitation within the zone of sulfate reduction on the modern Peruvian margin. Arning et al. (2009) further demonstrated that molecular fossils and carbonate-fluorapatite and sulfide-sulfur isotope data confirm the role of sulfate-reducing bacteria in the precipitation of phosphorite laminites.

How do we reconcile these contradictory views on the role of $\mathrm{pH}$ in apatite precipitation? Both experimental studies of sedimentary environments and theoretical predictions indicate that $\mathrm{pH}$ mediates carbonate speciation and carbonate ion concentration $\left(\left[\mathrm{CO}_{3}{ }^{2-}\right]\right.$; Zeebe and WolfGladrow 2001). In turn, experiments on francolite precipitation and dissolution reveal that carbonate ion concentration strongly influences apatite solubility (Jahnke 1984). Thus, the solubility of apatite is intimately linked to that of carbonate through a competition for calcium cations and a competition for carbonate anions in the case of carbonated phosphate minerals (Atlas and Pytkowicz 1977; Moore and Reddy 1994). In this regard, the $\mathrm{pH}$ sensitivity of apatite precipitation relates to carbonate saturation state in that carbonate dissolution/precipitation buffers calcium and carbonate ion concentration in pore waters (Sagemann et al. 1999; Jahnke 1984). At elevated pH (and/or low phosphorus concentrations), carbonate mineral precipitation is a stronger sink for calcium than other authigenic phases. At lower $\mathrm{pH}$, as is common in sulfidic pore waters, the saturation state of both carbonate and phosphate minerals is lower; under these conditions, the inability of calcium-phosphate minerals to precipitate may reflect true undersaturation or, alternatively, may relate to low carbonate ion concentration. Between these two $\mathrm{pH}$ end members, and given the necessary phosphorus availability, apatite precipitation may commence while carbonate precipitation remains less favorable.

How, then, did pore water $\mathrm{pO}_{2},\left[\mathrm{SO}_{4}{ }^{2-}\right], \mathrm{pH}$, the redox-dependent speciation of iron, and carbonate alkalinity interact to induce authigenic apatite precipitation in the Thorntonia Limestone? Within oxygenated pore waters, aerobic respiration would release phosphorus to pore water, and the resultant decrease in $\mathrm{pH}$ would spur $\mathrm{CaCO}_{3}$ dissolution, providing a source of $\mathrm{Ca}^{2+}$ for subsequent apatite precipitation. However, under oxygenated conditions, phosphorus released during aerobic respiration would advect back to the water column or become immobilized on the surface of iron-oxide minerals (Algeo and Ingall 2007). Any subsequent authigenic apatite precipitation would thus require heterotrophic metabolisms active deeper in the sediment column to respire these iron minerals and re-release phosphate to pore waters. In modern environments, sulfate-rich bottom waters accompany oxygen-replete environments, and this geochemical regime precludes a significant shuttle of Fe-bound $\mathrm{P}$ to the sediment column. In addition to the diminished flux of phosphorus to the sediment column, $\mathrm{P}$ retention is empirically low in sediments with high pore water sulfate concentrations (Caraco et al. 1989). For these reasons, oxygen-rich conditions would not seem to favor widespread apatite precipitation within the Thorntonia Limestone. Conversely, if pore water $\mathrm{O}_{2}$ and $\left[\mathrm{SO}_{4}{ }^{2-}\right]$ were low, and bioturbation limited or absent, then both organic carbon and the iron shuttle could deliver phosphorus to the sediment column (Shen et al. 2000; Creveling et al. 2014). In this scenario, anaerobic respiration pathways would release organic-bound $\mathrm{P}$ to Thorntonia pore waters and, of these metabolisms, iron reduction would release iron-oxide-bound P. However, if iron respiration were the primary remineralization metabolism then pore water $\mathrm{pH}$ would increase, allowing for $\mathrm{CO}_{3}{ }^{2-}$ ions to compete for $\mathrm{Ca}^{2+}$ ions in mineral formation. As such, diagenetic carbonate would precipitate, thus limiting the input of $\mathrm{Ca}^{2+}$ into pore waters for apatite authigenesis. On the other hand, if, during Thorntonia deposition, dissolved $\mathrm{O}_{2}$ was moderate, bioturbation limited, and sulfate availability sufficient to drive sulfate reduction (but not as high as modern concentrations), the resultant decrease in $\mathrm{pH}$ would stifle carbonate competition for pore water $\mathrm{Ca}^{2+}$, allowing for apatite precipitation.

In this hypothesized formulation of Thorntonia Limestone apatite authigenesis, modest sulfate concentrations optimize the scavenging of reactive iron through pyritization, limiting iron-bound $\mathrm{P}$ burial (e.g., Caraco et al. 1989). At the same time, pyrite precipitation precludes excess sulfide accumulation in pore waters, which would lower $\mathrm{pH}$ excessively and, therefore, increase apatite (and carbonate) solubility. This is relevant for two reasons. Firstly, phosphate-rich facies of the Thorntonia Limestone contain relatively high concentrations of pyrite (Figs. 6-7; Creveling et al. 2014). And secondly, sulfate levels in the midCambrian ocean appear to have been only a few percent of modern seawater, and would have been still lower in pore fluids (Gill et al. 2007, 2011; Warren 2010).

\section{Factors that Promoted Localized Apatite Precipitation in the Interiors of Thorntonia Skeletons}

The localization of authigenic phosphate within shell interiors suggests that the shells themselves physically impeded P-laden pore waters, preventing phosphorus loss from Thorntonia sediment. Chemical and biogeochemical processes within physically isolated shell interiors could then have pushed local pore waters toward critical supersaturation. The retention of carbonate textures in phosphatic steinkerns further suggests that as apatite grew within shell interiors it forced carbonate dissolution along a front of expanding phosphate mineral precipitation. Maliva and Siever (1988) showed how the force of crystallization associated with early diagenetic chert precipitation would promote carbonate dissolution along the growth front, preserving textures even as mineralogy changed. If, indeed, expanding apatite nucleation sourced alkalinity from dissolving proximal carbonates via force of crystallization (sensu Maliva and Siever 1988), this would have provided a positive feedback on apatite precipitation, with dissolving carbonate providing a local source of calcium ions within the matrix volume bounded by rigid skeletons. Such a mechanism could also operate over a larger spatial scale of fluid flow stagnation, accounting for the instances when apatite is observed to have nucleated as the cement within high porosity bioclastic grainstone (Fig. 2B). Whatever their proximal sources, the required calcium and phosphate ion loads were available, and pore waters of middle Thorntonia sediments were poised for apatite precipitation. What, then, dictated the spatial specificity of mineral nucleation within the cavities defined by skeletons?

We propose that the physical barrier to pore water exchange and equilibration provided by skeletons fostered supersaturation and apatite precipitation. Here, critical supersaturation was significant enough to circumvent kinetic barriers to apatite nucleation. That is, by stagnating fluid flow and locally raising $\mathrm{Ca}^{2+}$ concentrations through carbonate pressure dissolution, skeleton interiors could have maintained the geochemical conditions necessary for apatite precipitation. Such a mechanism would suggest a size limit on the interior volume likely to promote apatite precipitation, and this limit would relate to the length and timescale of diffusion in pore water; the front of apatite growth along 
the pressure dissolution boundary would compete with diffusive/advective loss of $\mathrm{Ca}^{2+}$ due to equilibration with sediment pore water surrounding the shell. In support of this argument, the maximum diameter of apatite steinkerns is about $2-3 \mathrm{~mm}$ even though Thorntonia skeletons reached much larger sizes (Fig. 2A). Moreover, phosphatization is absent from the central cavity of larger shells (Fig. 2A) and is often present in the smaller volume between concentric shells (Fig. 3J). This size is typical of small shelly fossil steinkerns observed globally and also approximates the maximum size noted for Örsten-style preservation of the carapace of microarthropods (Butterfield 2003).

\section{BIAS IN THE PHOSPHATIC PRESERVATION OF SMALL SHELLY FOSSILS}

Petrology shows that not all Thorntonia skeletons have been replicated by apatite. The probability of preservation as an apatite steinkern is influenced by shell size, shape, and even orientation (Figs. 2-3). Many authors have commented on the small size of phosphatized SSFs and the relative abundance in these faunas of mollusks and other conical forms. Others have additionally pointed out that larger shells occur in lower Cambrian successions but commonly remain apatite-free (e.g., Mus et al. 2008). Both observations are consistent with the pattern of selective phosphatization observed in the Thorntonia Limestone. Both empirical observation and the mechanism of phosphate emplacement proposed here suggest that there was a maximum volume within which phosphatization was likely to occur. Locally, exceptional phosphorus loading would have permitted larger steinkerns, but such conditions appear to have been uncommon. Understanding the relationship between phosphatized fossils and the overall diversity of earlier Cambrian faunas will require that the simple process of acid dissolution to free phosphatic fossils be complemented by careful petrology and novel techniques to access the morphological information in apatite-free remains.

\section{GLOBAL CONTROLS ON THE EDIACARAN-CAMBRIAN PHOSPHATIZATION TAPHONOMIC WINDOW}

Research on Thorntonia materials confirms that three factors were necessary for the formation of phosphatic fossils: (1) delivery of phosphorus to the sediment column through a combination of organicand iron-bound shuttles, (2) remobilization of phosphorus from these delivery shuttles via microbial metabolic pathways in anoxic pore waters, and (3) reprecipitation of phosphorus as apatite in small-scale, discrete geochemical environments, predominantly defined by the remains of small skeletal fossils (Creveling et al. 2014). Conditions 1 and 2 should apply more generally to phosphatic preservation. The specific circumstances of reprecipitation would, of course, vary depending on whether the fossils were preserved as steinkerns, phosphatic replicates precipitated on an organic/microbial template, or skeletal replacements. How then might the factors that enabled phosphate replication have contributed to the limited temporal duration and varying spatial distribution of the phosphatization taphonomic window?

Several interacting factors may have contributed to the shuttering of this distinctive taphonomic window, but the supply of organic-bound $\mathrm{P}$ to Cambrian sediment would not appear to be among them. The geologic record indicates that high fluxes of organic carbon into sediments began in the Archean Eon (e.g., Hayes and Waldbauer 2006) and has continued through to the modern. Therefore, one cannot appeal to secular variations in organic matter delivery alone as an explanation for the temporal bounds of the phosphatization window. In contrast, the delivery of phosphorus adsorbed to and coprecipitated with iron minerals depends on the redox state of subsurface water masses (e.g., März et al. 2008). Progressive ocean ventilation during the early Paleozoic Era (Berry and Wilde 1978; Bergman et al. 2004; Berner 2006; Dahl et al. 2010) would have affected the degree to which the Fe-shuttle could deliver phosphorus to the sediment column. Increasing sulfate levels as a function of bioturbation (Canfield and Farquhar 2009) would, for reasons outlined above, also have decreased the probability of penecontemporaneous phosphate mineralization in marine (but not lacustrine) environments. Nonetheless, it is important to bear in mind that whereas exceptional phosphatic fossil preservation declined through the Cambrian Period, economic phosphorite deposits continued to form episodically throughout the Phanerozoic Eon (Cook and Shergold 1984), with iron oxides delivered to the oceans contributing to both a continuing Fe-shuttle for phosphate sedimentation (O'Brien et al. 1990) and the scavenging of remobilized phosphorus in surface sediments (Delaney 1998).

Together, the processes that govern remobilization and subsequent trapping of phosphorus within sediments may provide a better explanation for closure of the Ediacaran-Cambrian phosphatization window. As noted above, ventilation of the oceans increased the proportion of oxic sediments on the seafloor, and, perhaps more importantly, bioturbation progressively irrigated sediments across Cambrian shelves and slopes, decreasing the probability of phosphorus remobilization while simultaneously shifting the locus of phosphogenesis to deeper environments (Brasier and Callow 2007). Microbial mats and small shelly fossils both provide mechanisms for retaining dissolved phosphorus in pore waters, increasing local saturation. Like small shells, mats can provide a physical barrier to advective phosphorus loss from underlying sediments and pore waters (Wilby et al. 1996). Furthermore, microbes within mats vigorously recycle phosphorus (Krajewski et al. 1994). In particular, sulfur-oxidizing bacteria have the potential to concentrate phosphate along the oxic-anoxic interface (Schulz and Schulz 2005). Delivery mechanisms for phosphorus aside, such internal sedimentary processes may well have concentrated $\mathrm{P}$ in surficial sediments of the Ediacaran Doushantuo Formation (Zhang et al. 1998; Bailey et al. 2013). With the radiation of metazoan grazers and burrowers, however, mat coverage would have declined, and other processes would have been necessary to trap and retain phosphorus within anoxic sediments. As is apparent in the Thorntonia Limestone, small shelly fossils trapped P-laden pore waters, enabling apatite precipitation as steinkerns. Microbially mediated apatite precipitation on organic templates (Briggs 2003) provided another means of local sedimentary phosphorus retention within the Georgina Basin and elsewhere.

If small conical to tubular skeletons - in contrast to larger shellsprovided a physical environment that facilitated apatite precipitation, then one might conclude that the presence of these organisms helps to define the boundaries of the phosphatization taphonomic window. That is, while phosphate minerals are necessary to preserve small skeletal fossils, small skeletal fossils may themselves have facilitated the nucleation of phosphate minerals. Following this logic, increasing shell size in mollusks, brachiopods and conical problematica from the Cambrian to the Ordovician (and beyond; Finnegan and Droser 2008; Novack-Gottshall 2008), might itself have decreased the probability of phosphatic steinkern formation. (Phosphatic steinkerns of foram tests occur in Cenozoic sediments; Rao and Lamboy 1995.) However, if skeletal size were the only variable dictating the dimensions of the phosphatization taphonomic window, then this should predict that the phosphatization taphonomic window should shift through time toward preservation of small or juvenile morphologies, rather than closing. In general, then, both biological (bioturbation, skeletal evolution) and environmental (increasing $\mathrm{O}_{2}$ and $\mathrm{SO}_{4}{ }^{2-}$ ) changes probably contributed to the closure of the Ediacaran-Cambrian phosphatization window, and did so interactively. How the window opened, however, is another matter.

Organic carbon deposition, iron-rich water masses and pore waters, and anoxia both within and above accumulating sediments were all common in Proterozoic oceans (e.g., Canfield et al. 2008; Planavsky et al. 2011), but phosphorite deposition was not (Cook and Shergold 1984). Indeed, the opening of the Ediacaran-Cambrian phosphatization taphonomic window and the onset of phosphorite ore deposition more or less coincide with 
putative increases in Ediacaran oxidation state (e.g., Canfield et al. 2008; Fike and Grotzinger 2008; Johnston et al. 2010; Lyons et al. 2014). Laakso and Schrag (2014) argue that in the low $\mathrm{pO}_{2}$ biosphere of the Proterozoic Eon, much of the phosphate freed by continental weathering would have been trapped in fluvial or estuarine environments by adsorption onto iron oxide minerals. If so, $\mathrm{P}$ delivery to the oceans would have increased dramatically during the Ediacaran Period. Planavsky et al. (2010) report that early Ediacaran seawater had elevated dissolved phosphate concentrations, which they attribute to enhanced physical weathering following the deglaciation of Cryogenian Snowball events. Increasing Ediacaran and Cambrian phosphate delivery to the oceans would also be predicted from the large increase in seawater ${ }^{87} \mathrm{Sr} /{ }^{86} \mathrm{Sr}$ observed in rocks of this age (Halverson et al. 2007) and thought to reflect Transgondwanan orogenesis (Campbell and Squire 2010). Thus, latest Neoproterozoic changes in tectonics and redox state may have opened the phosphatization window by increasing phosphorus delivery to the oceans.

\section{CONCLUSIONS}

Petrology makes it clear that not all small shelly fossils were equally likely to fossilize by steinkern formation; small conical fossils are commonly filled by phosphatic steinkerns while other skeletons remain phosphate mineral-free. Thus, phosphatization appears to impart a selectivity to fossil preservation, complicating efforts to understand patterns of diversity, biomass distribution, and ecological organization in the Thorntonia Limestone. We posit that an anoxic, ferruginous redox regime set the probability space for phosphatic preservation of small shelly fossils in the Thorntonia Limestone, but that the alignment of additional factors-from shell size to pore water saturation state-dictated the formation of individual phosphatic steinkerns. More broadly, we suggest that similar parameters define the Ediacaran-Cambrian window of phosphatization taphonomy. How this window opened remains a topic for research, but what kept it open for fifty million years or more was a unique alignment of environmental conditions intermediate between those of older Proterozoic and younger Phanerozoic oceans and an early stage of animal evolution during which metazoans provided organic and skeletal microenvironments for paleontologically informative phosphate deposition but had not yet irrigated sediments so thoroughly that phosphorus remobilization became restricted.

\section{ACKNOWLEDGMENTS}

We acknowledge the Northern Territory Geological Survey and Max Heckenberg and Jay Carter of the Alice Springs Core Library for access to core material. The Agouron Institute and the National Aeronautics and Space Administration (NASA) Astrobiology Institute (Massachusetts Institute of Technology node) provided financial support. We thank Phoebe Cohen for technical assistance in the acquisition of SEM data; Robert Gaines for conversations about Cambrian taphonomy; and Susannah Porter, an anonymous reviewer, and Associate Editor Jörn Peckmann for constructive comments that improved the content and clarity of this submission.

\section{REFERENCES}

Algeo, T., And Ingall, E., 2007, Sedimentary $C_{\text {org: }}$ P ratios, paleocean ventilation, and Phanerozoic atmospheric $\mathrm{pO}_{2}$ : Palaeogeography, Palaeoclimatology, Palaeoecology, v. 256, p. 130-155, doi: 10.1016/j.palaeo.2007.02.029.

Arning, E.T., Birgel, D., Brunner, B., And Peckmann, J., 2009, Bacterial formation of phosphatic laminites off Peru: Geobiology, v. 7, p. 295-307, doi: 10.1111/j.1472-4669. 2009.00197.x.

Atlas, E., And PytKowicz, R.M., 1977, Solubility behavior of apatites in seawater Limnology and Oceanography, v. 22, p. 290-300.

Bailey, J.V., Corsetti, F.A., Greene, S.E., Crosby, C.H., Liu, P., and Orphan, V.J., 2013, Filamentous sulfur bacteria preserved in modern and ancient phosphatic sediments: implications for the role of oxygen and bacteria in phosphogenesis: Geobiology, v. 11, p. 397-405, doi: 10.1111/gbi.12046.
Battison, L., AND Brasier, M.D., 2012, Remarkably preserved prokaryote and eukaryote microfossils within 1 Ga-old lake phosphates of the Torridon Group, NW Scotland: Precambrian Research, v. 196, p. 204-217, doi: 10.1016/j.precamres. 2011.12.012.

Bengtson, S., And Zhao, Y., 1992, Predatorial borings in late Precambrian mineralized exoskeletons: Science, v. 257, p. 367-369, doi: 10.1126/science.257.5068.367.

Bengtson, S., Conway Morris, S., Cooper, B.J., Jell, P.A., and Runnegar, B.N. 1990, Early Cambrian fossils from South Australia: Memoirs of the Association of Australian Palaeontologists, v. 9, p. 1-364.

Bengtson, S., Belivanova, V., Rasmussen, B., and Whitehouse, M., 2009, The controversial "Cambrian" fossils of the Vindhyan are real but more than a billion years older: Proceedings of the National Academy of Sciences, v. 106, p. 7729-7734, doi: $10.1073 /$ pnas.0812460106.

BEN-YAAKOV, S., 1973, $\mathrm{pH}$ buffering of pore water of recent anoxic marine sediments: Limnology and Oceanography, v. 18, p. 86-94.

Bergman, N.M., Lenton, T.M., and Watson, A.J., 2004, COPSE: a new model of biogeochemical cycling over Phanerozoic time: American Journal of Science, v. 304 p. 397-437, doi: 10.2475/ajs.304.5.397.

Bergmann, K.D., Grotzinger, J.P., and Fischer, W.W., 2013, Biological influences on seafloor carbonate precipitation: PALAIOS, v. 28, p. 99-115, doi: 10.2110 / palo.2012.p12-088r.

BERnER, R.A., 1973, Phosphate removal from sea water by adsorption on volcanogenic ferric oxides: Earth and Planetary Science Letters, v. 18, p. 77-86, doi: 10.1016/0012-821X (73)90037-X.

BERNER, R.A., 1984, Sedimentary pyrite formation: an update: Geochimica et Cosmochimica Acta, v. 48, p. 605-615, doi: 10.1016/0016-7037(84)90089-9.

BERNER, R.A., 2006, GEOCARBSULF: a combined model for Phanerozoic atmospheric $\mathrm{O}_{2}$ and $\mathrm{CO}_{2}$ : Geochimica et Cosmochimica Acta, v. 70, p. 5653-5664, doi: 10.1016/j.gca.2005.11.032

Berry, W. B. N., And Wilde, P., 1978, Progressive ventilation of the oceans: an explanation for the distribution of Lower Paleozoic black shales: American Journal of Science, v. 278, p. 257-275, doi: 10.2475/ajs.278.3.257.

Brasier, M.D., And Callow, R.H.T., 2007, Changes in the patterns of phosphatic preservation across the Proterozoic-Cambrian Transition: Memoirs of the Association of Australasian Palaeontologists, No. 34, p. 377-389.

BRIGGS, D.E.G., 2003, The role of decay and mineralization in the preservation of softbodied fossils: Annual Review of Earth and Planetary Science, v. 31, p. 275-301, doi: 10.1146/annurev.earth.31.100901.144746

Briggs, D.E.G., AND Kear, A.J., 1993, Fossilization of soft-tissue in the laboratory: Science, v. 259, p. 107-135, doi: 10.1126/science.259.5100.1439.

Briggs, D.E.G., AND Kear, A.J., 1994, Decay and mineralization of shrimps: PALAIOS, v. 9, p. 431-456, doi: 10.2307/3515135.

Butterfield, N.J., 2003, Exceptional fossil preservation and the Cambrian Explosion: Integrative and Comparative Biology, v. 43, p. 166-177, doi: 10.1093/icb/43.1.166.

Campbell, I.H., and SQuire, R.J., 2010, The mountains that triggered the late Neoproterozoic increase in oxygen: the second great oxidation event: Geochimica et Cosmochimica Acta, v. 74, p. 4187-4206, doi: 10.1016/j.gca.2010.04.064.

Canfield, D.E., and Farquhar, J., 2009, Animal evolution, bioturbation, and the sulfate concentrations of the oceans: Proceedings of the National Academy of Sciences, v. 106, p. 8123-8127, doi: 10.1073/pnas.0902037106.

Canfield, D.E., Poulton, S.W., Knoll, A.H., Narbonne, G.M., Ross, G., Goldberg, T., and Strauss, H., 2008, Ferruginous conditions dominated later Neoproterozoic deep-water chemistry: Science, v. 321, p. 949-952, doi: 10.1126/science.1154499.

Caraco, N.F., Cole, J.J., and Likens, G.E., 1989, Evidence for sulphate-controlled phosphorus release from sediments of aquatic systems: Nature, v. 341, p. 316-318, doi: $10.1038 / 341316 \mathrm{a} 0$.

Clark, L.L., Ingall, E.D., And Benner, R., 1998, Marine phosphorus is selectively remineralized: Nature, v. 393, p. 426-426, doi: 10.1038/30881.

Cook, P., And Shergold, J.H., 1984, Phosphorus, phosphorites and skeletal evolution at the Precambrian-Cambrian boundary: Nature, v. 10, p. 231-236, doi: 10.1038/ $308231 \mathrm{a} 0$.

Creveling, J.R., Johnston, D.T., Poulton, S.W., Kotrc, B., März, C., Schrag, D.P., AND Knoll, A.H., 2014, Phosphorus sources for phosphatic Cambrian carbonates: Geological Society of America Bulletin, v. 126, p. 145-163, doi: 10.1130/B30819.1.

Dahl, T.W., Hammarlund, E.U., Anbar, A.D., Bond, D.P.G., Gill, B.C., Gordon, G.W., Knoll, A.H., Nielsen, A.T., Schovsbo, N.H., and Canfield, D.E., 2010, Devonian rise in atmospheric oxygen correlated to the radiations of terrestrial plants and large predatory fish: Proceedings of the National Academy of Sciences, v. 107, p. 17911-17915, doi: 10.1073/pnas.1011287107.

Delaney, M.L., 1998, Phosphorus accumulation in marine sediments and the oceanic phosphorus cycle: Global Biogeochemical Cycles, v. 12, p. 563-572, doi: 10.1029/ 98GB02263.

Donoghue, P.C.J., Kouchinsky, A., Waloszek, D., Bengtson, S., Dong, X.-P., Val'kov, A.K., Cunningham, J.A., And Repetski, J.E., 2006, Fossilized embryos are widespread but the record is temporally and taxonomically biased: Evolution and Development, v. 8, p. 232-238, doi: 10.1111/j.1525-142X.2006.00093.x.

Dornbos, S.Q., Botjer, D.J., Chen, J.-Y., Gao, F., Oliveri, P., And Li, C.-W., 2006, Environmental controls on the taphonomy of phosphatized animals and animal embryos from the Neoproterozoic Doushantuo Formation, southwest China: Palaios, v. 21, p. 3-14, doi: 10.2110/palo.2004.p04-37.

Dunster, J.N., Kruse, P.D., Duffett, M.L., And Ambrose, G.J., 2007, Geology and resource potential of the southern Georgina Basin: Northern Territory Geological Survey, Digital Information Package DIP007. 
Edwards, C.T., Pufahl, P.K., Hiatt, E.E., And Kyser, T.K., 2012, Paleoenvironmental and taphonomic controls on the occurrence of Paleoproterozoic microbial communities in the $1.88 \mathrm{Ga}$ Ferriman Group, Labrador Trough, Canada: Precambrian Research, v. 212-213, p. 91-106, doi: 10.1016/j.precamres.2012.04.020.

Feely, R.A., Trefry, J.H., Massoth, G.J., and Metz, S., 1991, A comparison of the scavenging of phosphorus and arsenic from seawater by hydrothermal iron oxyhydroxides in the Atlantic and Pacific Oceans: Deep Sea Research Part A. Oceanographic Research Papers, v. 38, p. 617-623, doi: 10.1016/0198-0149(91)90001-V.

Feely, R.A., Trefry, J.H., Lebon, G.T., and German, C.R., 1998, The relationship between $\mathrm{P} / \mathrm{Fe}$ and $\mathrm{V} / \mathrm{Fe}$ ratios in hydrothermal precipitates and dissolved phosphate in seawater: Geophysical Research Letters, v. 25, p. 2253-2256, doi: 10.1029) 98GL01546.

Fike, D.A., And Grotzinger, J.P., 2008, A paired sulfate-pyrite $\delta^{34}$ S approach to understanding the evolution of the Ediacaran-Cambrian sulfur cycle: Geochimica et Cosmochimica Acta, v. 72, p. 2636-2648, doi: 10.1016/j.gca.2008.03.021.

Finnegan, S., And Droser, M.L., 2008, Body size, energetics, and the Ordovician restructuring of marine ecosystems: Paleobiology, v. 34, p. 342-359, doi: 10.1666/ 07074.1.

Föllmi, K.B., Badertscher, C., de Kaenel, E., Stille, P., John, C.M., Adatte, T., and Steinmann, P., 2005, Phosphogenesis and organic-carbon preservation in the Miocene Monterey Formation at Naples Beach, California: The Monterey hypothesis revisited: Geological Society of America Bulletin, v. 117, p. 589-619, doi: 10.1130/B25524.1

Froelich, P.N., Bender, M.L., Luedtke, N.A., Heath, G.R., and DeVries, T., 1982, The marine phosphorus cycle: American Journal of Science, v. 282, p. 474-511, doi: 10.1016/0025-3227(88)90095-3.

Froelich, P.N., Arthur, M.A., Burnett, W.C., Deakin, M., Hensley, V., Jahnke, R., Kaul, L., Kim, K.-H., Roe, K., Soutar, A., and Vathakanon, C., 1988, Early diagenesis of organic matter in Peru continental margin sediments: Phosphorite precipitation: Marine Geology, v. 80, p. 309-343.

Gill, B.C., Lyons, T.W., and Saltzman, M.R., 2007, Parallel, high-resolution carbon and sulfur isotope records of the evolving Paleozoic marine sulfur reservoir: Palaeogeography, Palaeoclimatology, Palaeoecology, v. 256, p. 156-173, doi: 10.1016/j.palaeo.2007.02.030

Gill, B.C., Lyons, T.W., Young, S., Kump, L., Knoll, A.H., and Saltzman, M.R., 2011, Geochemical evidence for widespread euxinia in the Later Cambrian ocean: Nature, v. 469, p. 80-83, doi: 10.1038/nature09700.

Glenn, C.R., AND Arthur, M.A., 1988, Petrology and major element geochemistry of Peru margin phosphorites and associated diagenetic minerals: authigenesis in modern organic-rich sediments: Marine Geology, v. 80, p. 231-267, doi: 10.1016/00253227(88)90092-8

Gubanov, A.P., And Peel, J.S., 2003, The early Cambrian helcionellid mollusc Anabarella vostokova: Palaeontology, v. 46, p. 1073-1087.

Hagadorn, J.W., Xiao, S., Donoghue, P.C.J., Bengtson, S., Gostling, N.J., Pawlowska, M., Raff, E.C., Raff, R.A., Turner, F.R., Chongyu, Y., Zhou, C., Yan, X., McFeely, M.B., Stampanoni, M., and Nealson, K.H., 2006, Cellular and subcellular structure of Neoproterozoic animal embryos: Science, v. 314, p. 291-294, doi: 10.1126/science.1133129.

Halverson, G.P., Dudas, F.Ö., Maloof, A.C., and Bowring, S.A., 2007, Evolution of the Sr-87/Sr-86 composition of Neoproterozoic seawater: Palaeogeography, Palaeoclimatology, Palaeoecology, v. 256, p. 103-129, doi: 10.1016/j.palaeo.2007.02.028.

Hayes, J.M., and Waldbauer, J.R., 2006, The carbon cycle and associated redox processes through time: Philosophical Transactions of the Royal Society B, v. 361, p. 931-950, doi: 10.1098/rstb.2006.1840.

Huldtgren, T., Cunningham, J.A., Yin, C., Stampanoni, M., Marone, F., Donoghue, P.C.J., AND Bengtson, S., 2011, Fossilized nuclei and germination structures identify Ediacaran "animal embryos" as encysting protists: Science, v. 334, p. 1696-1699, doi: $10.1126 /$ science. 1209537.

HuPFER, M., AND LewANDOWSKI, J., 2008, Oxygen controls the phosphorus release from lake sediments: a long-lasting paradigm in limnology: International Review of Hydrobiology, v. 93, p. 415-432, doi: 10.1002/iroh.200711054.

Ingall, E.D., Bustin, R.M., ANd VAN CAPPellen, P., 1993, Influence of water column anoxia on the burial and preservation of carbon and phosphorus in marine shales: Geochimica et Cosmochimica Acta, v. 57, p. 303-316, doi: 10.1016/00167037(93)90433-W

JAHNKE, R.A., 1984, The synthesis and solubility of carbonate fluorapatite: American Journal of Science, v. 284, p. 58-78, doi: 10.2475/ajs.284.1.58.

JahnKe, R.A., Emerson, S.R., Roe, K.K., And Burnett, W.C., 1983, The present day formation of apatite in Mexican continental margin sediments: Geochimica et Cosmochimica Acta, v. 47, p. 259-266, doi: 10.1016/0016-7037(83)90138-2.

Johnston, D.T., Poulton, S.W., Dehler, C., Porter, S., Husson, J., Canfield, D.E., AND KNOLl, A.H., 2010, An emerging picture of Neoproterozoic ocean chemistry: insights from the Chuar Group, Grand Canyon, USA: Earth and Planetary Science Letters, v. 290, p. 64-73, doi: 10.1016/j.eps1.2009.11.059.

Knoll, A.H., AND Vidal, G., 1980, Late Proterozoic vase-shaped microfossils from the Visingsö Beds, Sweden: Geologiska Foreningens i Stockholm Forhandlingar, v. 102, p. 207-211, doi: 10.1080/11035898009455157.

Konhauser, K.O., Lalonde, S.V., Amskold, L., and Holland, H.D., 2007, Was there really an Archean phosphate crisis?: Science, v. 315, p. 1234-1234, doi: 10.1126/ science. 1136328

Kouchinsky, A., Bengtson, S., Feng, W., Kutygin, R., and Val'kov, A., 2009, The lower Cambrian fossil anabaritids: affinities, occurrences, and systematics: Journal of Systematic Palaeontology, v. 7, p. 241-298, doi: 10.1017/S1477201909002715.
Kouchinsky, A., Bengtson, S., Runnegar, B., Skovsted, C., Steiner, M., and Vendrasco, M., 2012, Chronology of early Cambrian Biomineralization: Geological Magazine, v. 149, p. 221-251, doi: 10.1017/S0016756811000720.

Krajewski, K.P., Van Cappellen, P., Trichet, J., Kuhn, O., Lucas, J., MartínAlgarra, A., Prévôt, L., Tewari, V.C., Gaspar, L., Knight, R.I., and Lamboy, M., 1994, Biological processes and apatite formation in sedimentary environments, in K.B. Föllmi, ed., Concepts and Controversies in Phosphogenesis: Eclogae Geologicae Helvetiae, v. 87, p. 701-745.

Krom, M.D., AND Berner, R.A., 1981, The diagenesis of phosphorus in a nearshore marine sediment, Geochimica et Cosmochimica Acta, v. 45, p. 207-216.

LaAkso, T.A., And Schrag, D.P., 2014, Regulation of atmospheric oxygen during the Proterozoic: Earth and Planetary Science Letters, v. 388, p. 81-91, doi: 10.1016/ j.epsl.2013.11.049.

Lindsay, J.F., 2002, Supersequences, superbasins, supercontinents: evidence from the Neoproterozoic-early Palaeozoic basins of central Australia: Basin Research, v. 14, p. 207-223, doi: 10.1046/j.1365-2117.2002.00170.x.

Lyons, T.W., Reinhard, C.T., and Planavsky, N.J., 2014, The rise of oxygen in Earth's ocean and atmosphere: Nature, v. 506, p. 307-315, doi: 10.1038/nature13068.

MaAs, A., AND WaloszeK, D., 2001, Cambrian derivatives of the early arthropod stem lineage, pentastomids, tardigrades and lobopodians: an "Orsten" perspective: Zoologischer Anzeiger, v. 240, p. 451-459, doi: 10.1078/0044-5231-00053.

Maas, A., Braun, A., Dong, X.-P., Donoghue, P.C.J., Müller, K.J., Olempska, E., Repetski, J.E., Siveter, D.J., Stein, M., and Waloszek, D., 2006, The "Orsten": more than a Cambrian Konservat-Lagerstätte yielding exceptional preservation: Palaeoworld, v. 15, p. 266-282, doi: 10.1016/j.palwor.2006.10.005.

Maliva, R.G., AND Siever, R., 1988, Diagenetic replacement controlled by force of crystallization: Geology, v. 16, p. 688-691, doi: 10.1130/0091-7613(1988)016 $<0688$ :DRCBFO $>2.3 . \mathrm{CO} ; 2$

Maliva, R., Knoll, A.H., AND Siever, R., 1989, Secular change in chert distribution: a reflection of evolving biological participation in the silica cycle: PALAIOS, v. 4, p. 519-532, doi: $10.2307 / 3514743$.

Maloof, A.C., Porter, S.M., Moore, J.L., Dudás, F.Ö., Bowring, S.A., Higgins, J.M., Fike, D.A., AND EdDy, M.P., 2010, The earliest Cambrian record of animals and ocean geochemical change: Geological Society of America Bulletin, v. 122, p. 17311774, doi: 10.1130/B30346.1.

März, C., Poulton, S.W., Beckmann, B., Küster, K., Wagner, T., and Kasten, S., 2008, Redox sensitivity of P cycling during marine black shale formation: dynamics of sulfidic and anoxic, non-sulfidic bottom waters: Geochimica et Cosmochimica Acta, v. 72, p. 3703-3717, doi: 10.1016/j.gca.2008.04.025.

Moore, P.A., AND Reddy, K.R., 1994, Role of Eh and $\mathrm{pH}$ on phosphorous geochemistry in sediments of Lake Okeechobee, Florida: Journal of Environmental Quality, v. 23, p. 955-964, doi: 10.2134/jeq1994.00472425002300050016x.

Mus, M.M., Palacios, T., and Jensen, S., 2008, Size of the earliest mollusks: Did small helcionellids grow to become large adults?: Geology, v. 36, p. 175-178, doi: 10.1130/ G24218A.1

Nathan, Y., AND SASs, E., 1981, Stability relations of apatites and calcium carbonates: Chemical Geology, v. 34, p. 103-111, doi: 10.1016/0009-2541(81)90075-9.

Novack-Gottshall, P.M., 2008, Ecosystem-wide body-size trends in CambrianDevonian marine invertebrate lineages: Paleobiology, v. 34, p. 210-228, doi: 10.1666/0094-8373(2008)034[0210:EBTICM]2.0.CO;2.

O’Brien, G.W., Milnes, A.R., Veeh, H.H., Heggie, D.T., Riggs, S.R., Cullen, D.J. Marshall, J.F., AND CooK, P.J., 1990, Sedimentation dynamics and redox ironcycling: controlling factors for the apatite-glauconite association on the east Australian continental margin, in Notholt, A.J.G., and Jarvis, I., eds., Phosphorite Research and Development: Geological Society Special Publication, v. 52, p. 61-86, doi: 10.1144/GSL.SP.1990.052.01.06.

Parkhaev, P.Yu., and Karlova, G.A., 2011, Taxonomic richness and evolution of Cambrian mollusks of the genus Aldanella Vostokova, 1962 (Gastropods: Archaeobranchia): Palaeontological Journal, v. 45, p. 1145-1205.

Planavsky, N.J., Rouxel, O.J., Bekker, A., Lalonde, S.V., Konhauser, K.O., Reinhard, C.T., and Lyons, T.W., 2010, The evolution of the marine phosphate reservoir: Nature, v. 467, p. 1088-1090, doi: 10.1038/nature09485.

Planaviky, N.J., McGoldrick, P., Scott, C.T., Li, C., Reinhard, C.T., Kelly, A.E., Chu, X., Bekker, A., Love, G.D., and Lyons, T.W., 2011, Widespread iron-rich conditions in the mid-Proterozoic ocean: Nature, v. 477, p. 448-451, doi: 10.1038 nature10327.

PorTER, S.M., 2004a, Closing the phosphatization window: testing for the influence of taphonomic megabias on the pattern of small shelly fossil decline: PALAIOS, v. 19, p. 178-183, doi: 10.1669/0883-1351(2004)019<0178:CTPWTF $>2.0$.CO;2.

Porter, S.M., 2004b, Halkieriids in Middle Cambrian phosphatic limestones from Australia: Journal of Paleontology, v. 78, p. 574-590.

RaO, V.P., And Lamboy, M., 1995, Phosphorites from the Oman Margin, ODP Leg-117: Oceanologica Acta, v. 18, p. 289-307.

Sagemann, J., Bale, S.J., Briggs, D.E., and Parkes, R.J., 1999, Controls on the formation of authigenic minerals in association with decaying organic matter: an experimental approach: Geochimica et Cosmochimica Acta, v. 63, p. 1083-1095, doi: 10.1016/S0016-7037(99)00087-3.

Schulz, H.N., and Schulz, H.D., 2005, Large sulfur bacteria and the formation of phosphorite: Science, v. 307, p. 416-418, doi: 10.1126/science.1103096.

Shen, C., Pratt, B.R., Lan, T., Hou, J.-B., Chen, L., Hao, B.-Q., and Zhang, X.-G., 2013, The search for Orsten-type fossils in southern China: Palaeoworld, v. 22, p. 1-9, doi: 10.1016/j.palwor.2013.04.001. 
Shen, Y., Schidlowski, M., and Chu, X., 2000, Biogeochemical approach to understanding phosphogenic events of the terminal Proterozoic to Cambrian: Palaeogeography, Palaeoclimatology, Palaeoeocology, v. 158, p. 99-108, doi: 10.1016/S0031-0182(00)00033-X.

Skovsted, C.B., 2004, Mollusc fauna of the early Cambrian Bastion Formation of North-East Greenland: Bulletin of the Geological Society of Denmark, v. 51, p. 11-37.

Soetaert, K., Hofmann, A.F., Middelburg, J.J., Meysman, F.J., and Greenwood, J 2007, The effect of biogeochemical processes on pH: Marine Chemistry, v. 105, p. 30 51, doi: 10.1016/j.marchem.2006.12.012.

Southgate, P.N., 1986, Cambrian phoscrete profiles, coated grains, and microbial processes in phosphogenesis; Georgina Basin, Australia: Journal of Sedimentary Research, v. 56, p. 429-441, doi: 10.1306/212F893B-2B24-11D7-8648000102C1865D

Southgate, P.N., 1988, A model for the development of phosphatic and calcareous lithofacies in the Middle Cambrian Thorntonia Limestone, northeast Georgina Basin, Australia: Australian Journal of Earth Sciences, v. 35, p. 111-130, doi: 10.1080/ 08120098808729443

VAN Cappellen, P., AND Ingall, E.D., 1994, Benthic phosphorus regeneration, net primary production, and ocean anoxia: a model of the coupled marine biogeochemica cycles of carbon and phosphorus: Paleoceanography, v. 9, no. 5, p. 677-692, doi: 10.1029/94PA01455

Van Cappellen, P., and Ingall, E.D., 1996, Redox stabilization of the atmosphere and oceans by phosphorus-limited marine productivity: Science, v. 271, p. 493-496, doi: 10.1126/science.271.5248.493

WALoszeK, D., 2003, The "Orsten" window: a three-dimensionally preserved upper Cambrian meiofauna and its contribution to our understanding of the evolution of Arthropoda: Paleontological Research, v. 7, p. 71-88, doi: 10.2517/prpsj.7.71

Waloszek, D., Hinz, I., Shergold, J.H., And Müller, K.J., 1993, Three-dimensional preservation of arthropod soft integument form the Middle Cambrian of Australia: Lethaia, v. 26, p. 7-15, doi: 10.1111/j.1502-3931.1993.tb01504.x.
Walter, M.R., Veevers, J.J., Calver, C.R., and Grey, K., 1995, Neoproterozoic stratigraphy of the Centralian Superbasin, Australia: Precambrian Research, v. 73, p. 173-195, doi: 10.1016/0301-9268(94)00077-5.

WARREN, J.K., 2010, Evaporites through time: tectonic, climatic and eustatic controls in marine and nonmarine deposits: Earth Science Reviews, v. 98, p. 217-268, doi: 10.1016/j.earscirev.2009.11.004.

Wilby, P.R., And Briggs, D.E.G., 1997, Taxonomic trends in the resolution of detail preserved in fossil phosphatized soft tissue: GEOBIOS, v. 20, p. 493-502, doi: 10.1016/S0016-6995(97)80056-3.

Wilby, P.R., Briggs, D.E.G., Bernier, P., and Gaillard, C., 1996, Role of microbial mats in the fossilization of soft tissues: Geology, v. 24, p. 787-790, doi: 10.1130/00917613(1996)024<0787:ROMMIT>2.3.CO;2.

XiaO, S., AND Knoll, A.H., 1999, Fossil preservation in the Neoproterozoic Doushantuo phosphorite Lagerstätte: Lethaia, v. 32, p. 219-240, doi: 10.1111/ j.1502-3931.1999.tb00541.x

Xiao, S., Knoll, A.H., Yuan, X., and Pueschel, C., 2004, Phosphatized multicellular algae in the Neoproterozoic Doushantuo Formation, China, and the early evolution of florideophyte red algae: American Journal of Botany, v. 91, p. 214-227, doi: 10.3732/ajb.91.2.214.

Zeebe, R.E., and Wolf-Gladrow, D., 2001, $\mathrm{CO}_{2}$ in Seawater: Equilibrium, Kinetics, Isotopes: Elsevier Oceanography Book Series, Amsterdam, 346 p.

Zhang, Y., Yin, L., Xiao, S., And Knoll, A.H., 1998, Permineralized fossils from the terminal Proterozoic Doushantuo Formation, south China: The Paleontological Society Memoir 50, $52 \mathrm{p}$.

Received 3 January 2014; accepted 13 April 2014. 